\title{
Reproducible genomic DNA preparation from diverse crop species for molecular genetic applications
}

Kelvin T. Chiong ${ }^{1,4^{\dagger}}$, Mona B. Damaj ${ }^{{ }^{*} \dagger}$, Carmen S. Padilla ${ }^{1}$, Carlos A. Avila ${ }^{1,2}$, Shankar R. Pant ${ }^{1}$, Kranthi K. Mandadi ${ }^{1,3}$, Ninfa R. Ramos ${ }^{1}$, Denise V. Carvalho ${ }^{1,5}$ and T. Erik Mirkov ${ }^{1,3^{*}}$

\begin{abstract}
Background: Several high-throughput molecular genetic analyses rely on high-quality genomic DNA. Copurification of other molecules can negatively impact the functionality of plant DNA preparations employed in these procedures. Isolating DNA from agronomically important crops, such as sugarcane, rice, citrus, potato and tomato is a challenge due to the presence of high fiber, polysaccharides, or secondary metabolites. We present a simplified, rapid and reproducible SDS-based method that provides high-quality and -quantity of DNA from small amounts of leaf tissue, as required by the emerging biotechnology and molecular genetic applications.
\end{abstract}

Results: We developed the TENS-CO method as a simplified SDS-based isolation procedure with sequential steps of purification to remove polysaccharides and polyphenols using 2-mercaptoethanol and potassium acetate, chloroform partitioning, and sodium acetate/ethanol precipitation to yield high-quantity and -quality DNA consistently from small amounts of tissue $(0.15 \mathrm{~g})$ for different plant species. The method is simplified and rapid in terms of requiring minimal manipulation, smaller extraction volume, reduced homogenization time (20 s) and DNA precipitation (one precipitation for $1 \mathrm{~h}$ ). The method has been demonstrated to accelerate screening of large amounts of plant tissues from species that are rich in polysaccharides and secondary metabolites for Southern blot analysis of reporter gene overexpressing lines, pathogen detection by quantitative $P C R$, and genotyping of disease-resistant plants using marker-assisted selection.

Conclusion: To facilitate molecular genetic studies in major agronomical crops, we have developed the TENS-CO method as a simple, rapid, reproducible and scalable protocol enabling efficient and robust isolation of high-quality and -quantity DNA from small amounts of tissue from sugarcane, rice, citrus, potato, and tomato, thereby reducing significantly the time and resources used for DNA isolation.

Keywords: Genomic DNA extraction, Simplified SDS method, Polyphenols, Polysaccharides, Saccharum spp. hybrids, Oryza sativa, Citrus sinensis, Solanum lycopersicum, Solanum tuberosum

\footnotetext{
*Correspondence: mbdamaj@ag.tamu.edu; e-mirkov@tamu.edu; e-mirkov@hotmail.com

${ }^{\dagger}$ Kelvin T. Chiong and Mona B. Damaj contributed equally to this work

${ }^{1}$ Texas A\&M AgriLife Research and Extension Center, 2415 East US

Highway 83, Weslaco, TX 78596, USA

3 Department of Plant Pathology and Microbiology, Texas A\&M University,

2132 TAMU, College Station, TX 77843, USA

Full list of author information is available at the end of the article
} 


\section{Background}

Preparation of high-quality genomic DNA is critical for biotechnology applications, as well as molecular genetic studies. Isolation of DNA from agronomically important crops, such as sugarcane, rice, citrus, potato and tomato remains a limiting step due to the presence of high polysaccharides, polyphenols, and other secondary metabolites [1-5]. Furthermore, levels of these compounds accumulate in plants under abiotic and biotic stresses, such as drought or pathogen infection [6, 7]. These metabolites tend to copurify with DNA, interfering with downstream applications, including Southern blot hybridization, marker-assisted polymorphism detection, next-generation sequencing, PCR sequencing, and bacterial artificial chromosome library construction [5, 8-11].

A growing number of methods exist for isolating DNA from tissues of plant species with a high content of polysaccharides and/or secondary metabolites. These methods mainly use detergent-based extraction buffers containing cetyltrimethylammonium bromide (CTAB) [12-16], sodium dodecyl sulfate (SDS) [17-20] and guanidine [21]. Some methods have included in the CTAB or SDS extraction buffer, sugars such as mannitol [22] or sorbitol $[23,24]$, antioxidants such as PVP-40 (polyvinylpyrrolidone; molecular weight, 40,000) [3, 5, 11, 25-30], or high salt [31,32]. Most methods use phenol/ chloroform for purification of the extracted DNA; while others add a purification step, by binding the extracted DNA to glass fiber coated plate wells [33] or to an anion exchange column [34].

Here, we describe a simple, rapid and scalable procedure for isolation of high-quality and -quantity DNA from sugarcane, rice, citrus, potato, and tomato leaf tissue. The procedure is a simplified SDS extraction method with sequential steps of purification to remove polysaccharides and polyphenols using 2-mercaptoethanol and potassium acetate, chloroform partitioning, and sodium acetate/ethanol precipitation. We achieved high yields and quality of DNA consistently from small amounts of tissue samples for these different plant species in a short period of time with this new isolation method.

\section{Methods}

\section{Genetic constructs and plant transformation}

The gus gene (gusA, 1.811 kilobase [kb]) was cloned into the binary vector pBIN34S carrying the selectable marker neomycin phosphotransferase gene, to produce pBIN34S:GUS [35] for citrus transformation. pBIN34S:GUS was transformed into sweet orange (Citrus sinensis L. cv. Hamlin) and potato (Solanum tuberosum L. cv. Atlantic) using Agrobacterium tumefaciens strain EHA105 [36] and seedling-derived epicotyl (citrus) and internodal (potato) segments [35].
The pCAMBIA1301 binary vector carrying the SHDIR16:GUS construct (gus gene under the control of the culm-regulated Saccharum spp. hybrids dirigent16 promoter) [37] was used for transformation of rice (Oryza sativa subspecies japonica, cultivar Taipei 309), using embryo-derived calli and A. tumefaciens strain EHA105 [38].

The SHDIR16:GUS construct together with the Ubi1:BAR/pUC8 (pAHC20) plasmid containing the bar (bialaphos resistance) selectable marker (under the control of the maize ubiquitin 1 promoter) [39], were introduced into embryonic callus established from young leaf bases and immature flowers of commercial sugarcane (Saccharum spp. hybrids, cv. CP72-1210) by particle gun bombardment, as described previously [40].

\section{Plant growth}

Sugarcane, rice and sweet orange were grown in RediEarth mix (Scotts, Hope, AR) in a controlled-environment greenhouse $\left(28{ }^{\circ} \mathrm{C}\right.$ with 14 -h-light/10-h-dark). Tomato and potato were grown in Sunshine MVP mix (Sun Gro Horticulture, Agwam, MA, USA) in a controlled-environment room with sodium lamps $\left(24{ }^{\circ} \mathrm{C}\right.$ with 14-h-light/10-h-dark).

\section{DNA isolation protocol}

A simple and rapid protocol (TENS-CO), as described below, was developed for isolating DNA from sugarcane, rice, citrus, potato, and tomato tissues. The protocol steps are also outlined in Table 1.

\section{Isolation of DNA by the TENS-CO method}

Extraction Fresh tissue from young leaves $(0.15 \mathrm{~g})$ (snap frozen in liquid nitrogen, mostly used) was homogenized in $2 \mathrm{ml}$ screw-cap microcentrifuge tubes for $20 \mathrm{~s}$ at $5000 \mathrm{rpm}$ with the Precellys 24 homogenizer (MO BIO Laboratories, Carlsbad, CA, USA) in the presence of two steel BB air gun beads (BB refers to the bead size, $4.5 \mathrm{~mm}$-diameter) (Walmart Supercenter, Bentonville, AR, USA). Up to 24 samples could be processed at a time with this homogenizer. Alternative to liquid nitrogen, microcentrifuge tubes with

\section{Table 1 Major steps of the TENS-CO protocol used for plant genomic DNA isolation

\begin{tabular}{ll}
\hline (1) Extraction & TENS buffer ${ }^{\mathrm{a}}$ and $\mathrm{CO}^{\mathrm{b}}$ \\
& $5 \mathrm{M}$ potassium acetate \\
& $3 \mathrm{M}$ sodium acetate $(\mathrm{pH} 5.2)(0.1 \times$ volume $)$ \\
& Ethanol $(2.0 \times$ volume $)$
\end{tabular}

a TENS buffer: $100 \mathrm{mM}$ Tris (hydroxymethyl) aminomethane (Tris Base) (pH 8.0), 50 mM ethylenediamine-tetraacetic acid (EDTA) (pH 8.0), $500 \mathrm{mM}$ sodium chloride $(\mathrm{NaCl}), 1 \%(\mathrm{w} / \mathrm{v})$ sodium dodecyl sulfate $(\mathrm{SDS})$, and $2 \%(\mathrm{v} / \mathrm{v})$ 2-mercaptoethanol

b CO chloroform:octanol (24:1) 
leaf samples were frozen at $-80{ }^{\circ} \mathrm{C}$ for at least $1 \mathrm{~h}$ before homogenizing. Extraction buffer $(1.25 \mathrm{ml})$ was added to each homogenized leaf sample and mixed by vortexing. The extraction buffer consisted of $100 \mathrm{mM}$ Tris (hydroxymethyl) aminomethane (Tris Base), $50 \mathrm{mM}$ ethylenediaminetetraacetic acid (EDTA) (pH 8.0), $500 \mathrm{mM}$ sodium chloride $(\mathrm{NaCl}), 1 \%(\mathrm{w} / \mathrm{v})$ sodium dodecyl sulfate (SDS), and $2 \%(\mathrm{v} / \mathrm{v})$ 2-mercaptoethanol. The homogenate was incubated at $65^{\circ} \mathrm{C}$ for $30 \mathrm{~min}$ and centrifuged at $10,000 \times g$ for $10 \mathrm{~min}$. The collected supernatant $(1.3 \mathrm{ml})$ was mixed with $0.4 \times$ volume of $5 \mathrm{M}$ potassium acetate $(\mathrm{KOAc})(520 \mu \mathrm{l})$, vigorously mixed by hand, and incubated on ice for $20 \mathrm{~min}$. The mixture was centrifuged at $10,000 \times g$ for $15 \mathrm{~min}$ at $4{ }^{\circ} \mathrm{C}$. The supernatant $(1.4 \mathrm{ml})$ was collected and mixed with $0.5 \times$ volume of chloroform:octanol (24:1) $(700 \mu \mathrm{l})$ vigorously by inversion for $10 \mathrm{~min}$, and centrifuged at $13,000 \times g$ for $15 \mathrm{~min}$. The upper aqueous phase $(1.2 \mathrm{ml})$ was collected, mixed with $66 \mu \mathrm{g}$ of RNase $(6.6 \mu \mathrm{l}$ of $10 \mathrm{mg} / \mathrm{ml})$, and incubated in a $37{ }^{\circ} \mathrm{C}$ water bath for $1 \mathrm{~h}$.

Precipitation The mixture was added to $0.1 \times$ volume of $3 \mathrm{M}$ sodium acetate ( $\mathrm{pH}$ 5.2) and $2 \times$ volume of ice-cold $100 \%(\mathrm{v} / \mathrm{v})$ ethanol and incubated at $-20{ }^{\circ} \mathrm{C}$ for $1 \mathrm{~h}$. The DNA pellet was recovered by centrifugation at $12,000 \times g$ for $10 \mathrm{~min}$ at $4{ }^{\circ} \mathrm{C}$, washed with $70 \%(\mathrm{v} / \mathrm{v})$ ethanol, airdried, and dissolved in $200-400 \mu \mathrm{l}$ of nuclease-free water.

\section{Comparative analysis of the TENS-CO method with standard isolation methods}

An SDS-based method (modified from Tai and Tanksley [20]) and a CTAB-based method (modified from Chee et al. [41]) conventionally used for sugarcane and citrus (3.0 g of tissue), respectively, were tested in parallel with the TENS-CO method ( $0.15 \mathrm{~g}$ of tissue) for DNA extraction. Two commercial kits, PowerPlant Pro DNA Isolation Kit (SDS-based; MO BIO Laboratories; for rice, potato and tomato) (0.15 g of tissue) and Synergy Plant DNA Extraction Kit (CTAB-based; OPS Diagnostics, Lebanon, NJ, USA; for potato and tomato) (0.05 g of tissue) were also tested.

\section{DNA yield and purity}

DNA was quantified by measuring the concentration and absorbance (A) level at 230, 260, and $280 \mathrm{~nm}$ using a NanoDrop 1000 Spectrophotometer (Thermo Fisher Scientific, Wilmington, DE, USA). The absorbance ratios of $A_{260: 280}$ and $A_{260: 230}$ were used to determine the purity of DNA. The quality of DNA was examined by electrophoresis on $0.8 \%$ agarose gels stained with ethidium bromide.

\section{Southern blot analysis}

Genomic DNA was isolated from young leaves of 6-month-old transgenic sweet orange and potato plants, and 3-4 month-old transgenic sugarcane and rice plants. Genomic DNA (15 $\mu$ g each lane) was digested overnight with either HindIII (sweet orange and potato) or SacI (sugarcane and rice), electrophoresed on $0.8 \%(\mathrm{w} / \mathrm{v})$ agarose gels and transferred to nylon membranes (Amersham Hybond-XL, GE Healthcare Bio-Sciences Corp., Piscataway, NJ, USA) in an alkaline solution (0.4 M sodium hydroxide) [42].

DNA blots were hybridized with the full-length coding region of $g u s A(2.28 \mathrm{~kb})$. The gusA-specific probe was obtained from pAHC27 [39] by BamHI and SacI digestion. Probes were labeled with $\left[{ }^{32} \mathrm{P}\right] \alpha-\mathrm{dCTP}$ by random priming using the Random Primers DNA Labeling kit (Invitrogen, Carlsbad, CA, USA). Pre-hybridization, hybridization, washing and detection of DNA gel blots were performed as described by Mangwende et al. [43], using Church's buffer.

\section{Quantitative real-time PCR}

DNA was isolated from leaves of 6 week-old healthy and Candidatus Liberibacter solanacearum (Lso) infected potato plants. Top-most fully expanded non-inoculated leaves were collected from healthy and Lso infected plants (10 psyllids per plant) at 21 days post infestation. Quantitative real-time PCR (qPCR) was used to detect Lso in infected and healthy samples with CL-ZC primers specific for detection of Lso [44] and TOMATO RIBOSOMAL PROTEIN L2 (RPL2) (GenBank accession no. X64562) endogenous reference gene primers [45]. The primer sets for Lso (CL-ZC-F: 5'-ACCCTGAACCTCAATTTTACTGAC-3' and CL-ZC-R: 5'-TCGGATTTAGGAGTGGGTAAGTGG-3') and RPL2 (RPL2-F: 5'-GAGG-GCGTACTGAGAAACCA-3'; RPL2R: 5'-CTTTTGTCCAGGAGGTGCAT-3') were used to perform qPCR on a CFX384 ${ }^{\mathrm{TM}}$ Real-Time PCR Detection System (Bio-Rad Laboratories, Inc., Hercules, CA, USA) with the $\mathrm{iTaq}^{\mathrm{TM}}$ universal SYBR ${ }^{\circledR}$ Green supermix (Bio-Rad Laboratories, Inc.), $0.2 \mu \mathrm{M}$ of target specific primer and $50 \mathrm{ng}$ of genomic DNA, according to the manufacturer's instructions. qPCR was performed on DNA from four biological samples with three technical replicates per sample using the following conditions: one cycle at $95^{\circ} \mathrm{C}$ for $3 \mathrm{~min}$, 39 two-step cycles each at $95^{\circ} \mathrm{C}$ for $15 \mathrm{~s}$ and $55^{\circ} \mathrm{C}$ for $30 \mathrm{~s}$, and a final melting curve of $65-95{ }^{\circ} \mathrm{C}$ for $5 \mathrm{~s}$. Results were analyzed and recorded as $C_{t}$ (threshold cycle) values, and melt curve analysis was performed to detect non-specific amplification. Quantification of Lso in the infected versus healthy tissues was determined relative to that of the RPL2 gene using the comparative $C_{t}$ method $\left(2^{-\Delta \Delta C t}\right)$ [46].

\section{Marker-assisted selection}

The co-dominant Sequence Characterized Amplified Regions (SCAR) marker P6-25 linked to Tomato yellow 
leaf curl virus (TYLCV) resistance gene Ty-3 [47] was used to select for resistant plants. DNA was isolated from leaves of segregating tomato lines at the Vegetable Breeding Program, Texas A\&M AgriLife Research-Weslaco, Texas. PCR was performed on a C1000 Touch $^{\mathrm{TM}}$ thermal cycler (Bio-Rad Laboratories, Inc.) in a total reaction volume of $25 \mu \mathrm{l}$ using $100 \mathrm{ng}$ of DNA, $0.2 \mu \mathrm{M}$ of each target specific primer, 1.0 U of Platinum ${ }^{\text {TM }}$ Taq DNA polymerase (Invitrogen), $1 \times$ PCR buffer, $1.5 \mathrm{mM}$ of $\mathrm{MgCl}_{2}$ and $0.2 \mathrm{mM}$ of each dNTP. PCR conditions were: one denaturing cycle at $94{ }^{\circ} \mathrm{C}$ for $4 \mathrm{~min}, 35$ cycles each at $94{ }^{\circ} \mathrm{C}$ for $30 \mathrm{~s}, 53^{\circ} \mathrm{C}$ for $1 \mathrm{~min}$ and $72{ }^{\circ} \mathrm{C}$ for $1 \mathrm{~min}$, and a final extension cycle at $72{ }^{\circ} \mathrm{C}$ for $10 \mathrm{~min}$. PCR amplicons were separated by electrophoresis on a $1.5 \%(\mathrm{w} / \mathrm{v})$ agarose gel stained with ethidium bromide. Allele identification was performed based on fragment sizes as reported by Ji et al. [47].

\section{Results and discussion}

\section{Preparation of high-quality and -quantity DNA by the} TENS-CO method

The TENS-CO method yielded DNA with high-purity and -integrity from liquid nitrogen and $-80{ }^{\circ} \mathrm{C}$ frozen tissue as reflected by the intact bands in gel electrophoresis (Fig. 1a, b) and low levels of polysaccharides/phenols as indicated by the spectrophotometric $\mathrm{A}_{260}: \mathrm{A}_{230}$ ratio values of 2.04, 2.18, 2.08, 2.23 and 2.10 for sugarcane, rice, sweet orange, potato, and tomato, respectively (Table 2). Ratio values above 1.9 are considered acceptable and indication of high-quality DNA. The presence of high amounts of $\mathrm{NaCl}(0.5 \mathrm{M})$ in the TENS-CO extraction buffer was efficient in increasing the solubility of polysaccharides, reducing their coprecipitation with the DNA in subsequent steps [48]. In addition, the incorporation of 2-mercaptoethanol into the extraction buffer helped in reducing phenolics oxidation and precipitation with DNA.

The TENS-CO method was also efficient in removing proteins, with DNA samples repeatedly exhibiting $A_{260}: A_{280}$ ratio values of 1.85 for sugarcane, 1.93 for rice, 2.00 for sweet orange, 1.91 for potato, and 1.93 for tomato (Table 2). The $\mathrm{A}_{260}: \mathrm{A}_{230}$ and $\mathrm{A}_{260}: \mathrm{A}_{280}$ ratios for MO BIO PowerPlant Pro DNA Isolation and Synergy Plant DNA kits were acceptable (Table 2), but the low yield restricts the applicability of the isolated DNA (Table 2). The incorporation of high concentrations of KOAc $(5 \mathrm{M})$ aided in neutralizing the lysis produced by the TENS-CO buffer reaction and precipitating proteins that bind to SDS, thereby eliminating excess of proteins that form in the pellet after centrifugation.

The TENS-CO method produced good yields of DNA, equally from liquid nitrogen and $-80{ }^{\circ} \mathrm{C}$ frozen tissue, for sugarcane $(0.46 \pm 0.05 \mu \mathrm{g} / \mathrm{mg})$, rice $(0.35 \pm 0.05 \mu \mathrm{g} /$ $\mathrm{mg})$, sweet orange $(0.64 \pm 0.08 \mu \mathrm{g} / \mathrm{mg})$, potato $(0.50 \pm 0.04 \mu \mathrm{g} / \mathrm{mg})$, and tomato $(0.66 \pm 0.06 \mu \mathrm{g} / \mathrm{mg})$ (Table 2). The DNA concentrations were significantly higher than those obtained with the high-volume detergent-based standard isolation methods containing SDS (sugarcane, $0.10 \mu / \mathrm{mg}$ ) and CTAB (sweet orange, $0.12 \mu \mathrm{g} /$ mg) (Table 2). The commercial kits yielded low amounts of DNA for all species tested, i.e. rice $(0.10 \mu \mathrm{g} / \mathrm{mg}$ for the SDS-based MO BIO PowerPlant Pro DNA isolation kit), potato $(0.05 \mu \mathrm{g} / \mathrm{mg}$ for the MO BIO kit and $0.2 \mu \mathrm{g} / \mathrm{mg}$ for the CTAB-based Synergy Plant DNA kit), and tomato $(0.05 \mu \mathrm{g} / \mathrm{mg}$ for the MO BIO kit and $0.11 \mu \mathrm{g} / \mathrm{mg}$ for the Synergy Plant DNA kit) (Table 2); furthermore, there was a mild degradation of the DNA as a result of the harsh homogenization suggested in the manufacturer's protocols (Fig. 1c).

The TENS-CO method also resulted in higher yields of DNA from sugarcane than those reported by Vaze et al. [49] $(0.025-0.1 \mu \mathrm{g} / \mathrm{mg})$, and Honeycutt et al. [50] $(0.28 \mu \mathrm{g} / \mathrm{mg})$ (Additional file 1: Table S1). Similar results were observed for citrus and tomato DNA yields, which were less than 0.15 and $0.08 \mu \mathrm{g} / \mathrm{mg}$, respectively (Additional file 1: Table S1) [4, 10, 51].

Optimization of the TENS-CO isolation method was achieved by reducing the leaf tissue weight from 0.4 to $3.0 \mathrm{~g}$ usually required for standard isolation methods for sugarcane, rice, citrus, potato and tomato to 0.15 . Automated tissue homogenization allowed the extraction of 24 samples in a very short period of time $(20 \mathrm{~s})$ in small tubes $(2 \mathrm{ml})$, using a reduced extraction volume $(1.25 \mathrm{ml})$. High-throughput extractions could be achieved with TENS-CO by using higher capacity homogenizers.

The TENS-CO method is a simplified DNA isolation technique that uses SDS and an antioxidant (2-mercaptoethanol) for extraction and one precipitation step (ethanol) to yield high-quantity and -quality DNA from small amounts of tissue $(0.15 \mathrm{~g})$. The method is simplified and rapid in terms of requiring minimal manipulation, smaller extraction volume, reduced time needed for tissue homogenization (20 s) and DNA precipitation (one precipitation for $1 \mathrm{~h}$ ). The procedure is scalable and can be used to study a larger number of samples.

\section{DNA isolated with the TENS-CO method is suitable for Southern blot analysis}

Southern blot analysis is a robust technique widely used for molecular characterization of transgenics. A total of 11 sugarcane, 17 rice, six sweet orange and seven potato transgenic lines constitutively expressing the gus $\mathrm{A}$ reporter gene were used in this study. To demonstrate the suitability of the TENS-CO method for detecting specific genes, we determined the presence of the gusA transgene in transgenic sugarcane, rice, sweet orange and 


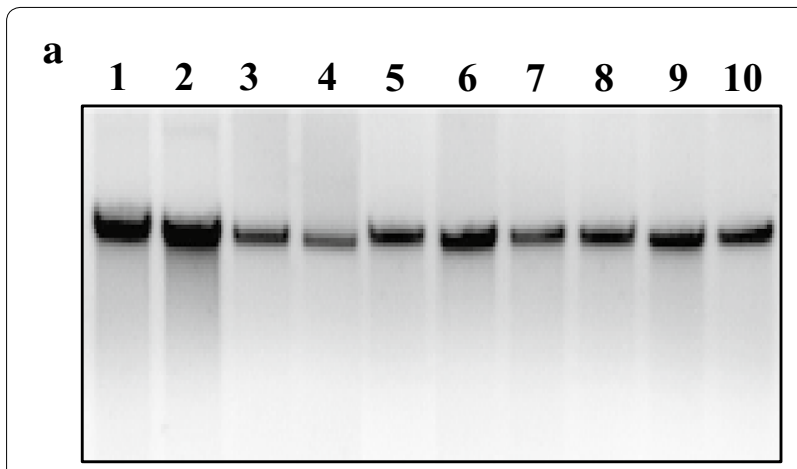

Lanes 1-2= Sugarcane; lanes 3-4= Potato; lanes 5-6= Rice; lanes 7-8= Sweet orange; and lanes 9-10= Tomato.

b

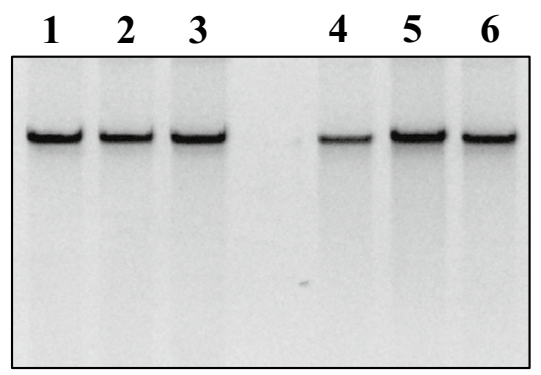

Lanes 1-3= Potato DNA isolated with the TENS-CO method from leaf tissue snap frozen in liquid nitrogen; and lanes 4-6= Potato DNA isolated with the TENS-CO method from leaf tissue frozen to $80{ }^{\circ} \mathrm{C}$.

c

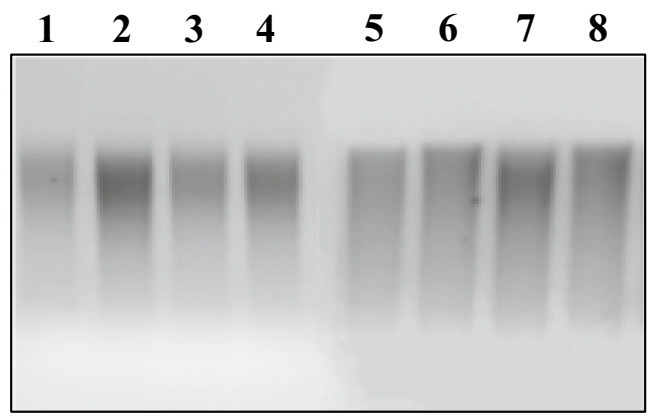

Lanes 1-4= Potato DNA isolated with the Synergy Plant DNA Extraction Kit (OPS Diagnostics, Lebanon, NJ); and lanes 5-8= Rice DNA isolated with the PowerPlant Pro DNA Isolation Kit (MO BIO Laboratories, Carlsbad, CA).

Fig. 1 Assessment of the integrity of the genomic DNA isolated with the TENS-CO method by gel electrophoresis. DNA extracted from leaves of different plant species using TENS-CO after freezing (snap) in liquid nitrogen $(\mathbf{a}, \mathbf{b})$ or to $-80^{\circ} \mathrm{C}(\mathbf{b})$ as well as two commercial DNA isolation kits (c) was electrophoresed on a $0.8 \%(\mathrm{w} / \mathrm{v})$ agarose gel stained with ethidium bromide (approximately 300-400 ng per lane) potato lines using Southern blot hybridization. Sugarcane and sweet orange genomic DNA, isolated by the TENS$\mathrm{CO}$ and the standard methods (SDS- and CTAB-based methods for sugarcane and sweet orange, respectively) was digested with HindIII and SacI, respectively and subsequently hybridized with the gusA probe. Transgenic sugarcane (Fig. 2) and sweet orange (Fig. 3) lines exhibited similar profiles of DNA isolated with the TENS-CO and standard methods. Binding of the gus $A$ probe was as specific with DNA extracted by the TENS-CO as the one isolated with the standard methods (Figs. 2, 3, respectively), indicating that the DNA is intact. Furthermore, DNA extracted from the rice and potato transgenic lines using the TENS-CO and the traditional SDS- and CTABbased methods displayed the same DNA hybridization profiles (data not shown). This indicates that the DNA isolated with the TENS-CO method is reproducible and can be used for screening a large number of transgenic lines of diverse plant species with high polysaccharides and secondary metabolites.

\section{DNA isolated with the TENS-CO method is successfully used for molecular diagnostics and pathogen detection}

Candidatus Liberibacter solanacearum (Lso), an unculturable, phloem-limited bacterium transmitted by the potato/tomato psyllid Bactericera cockerelli, causes Zebra chip disease, which is a serious threat to potato and other Solanaceous crops, leading to significant economic losses in Central America, Mexico and the United States [52-54]. To date, no Lso-resistant varieties of potato or tomato have been reported. Recent control strategies of Zebra chip disease involved the use of insecticides to control psyllid populations in Lso-infected fields. Early detection of Lso in host leaves is crucial to strategies for the containment of the disease in its early stages, and qPCR is commonly used for this purpose [53-55]. The sensitivity and specificity of qPCR to detect pathogen in host tissue is dependent on various factors, including the quality of DNA. We tested the quality of DNA extracted by the TENS-CO method, as compared to the standard CTAB method for the detection of the Lso titer present in leaves of four potato plants infected with Lso (Lso1, Lso2, Lso3 and Lso4) using qPCR analysis. The qPCR results (from four biological samples and three technical replicates per sample) showed the presence of higher bacterial levels in all four Lso-infected potato samples as compared to non-infected ones, using DNA isolated with both TENS-CO and standard CTAB methods (Fig. 4a, b). The Lso levels detected with DNA from both methods were comparable, i.e. they were 434.5 (TENS-CO) or 338.6 (CTAB), 552.6 (TENS-CO) or 456.8 (CTAB), 573.6 (TENS-CO) or 486.8 (CTAB) and 675.6 (TENS-CO) or 606.8 (CTAB) fold more in Lso1, Lso2, Lso3 and Lso4 
Table 2 Comparison of the TENS-CO method with standard DNA isolation procedures for the crop species used in the current study

\begin{tabular}{|c|c|c|c|}
\hline \multirow[t]{2}{*}{ Method } & \multirow[t]{2}{*}{ DNA yield ( $\mu \mathrm{g} / \mathrm{mg}$ tissue) } & \multicolumn{2}{|l|}{ DNA purity } \\
\hline & & $A_{260}: A_{230}$ & $A_{260}: A_{280}$ \\
\hline \multicolumn{4}{|l|}{ Grass } \\
\hline \multicolumn{4}{|l|}{ Sugarcane (Saccharum spp. hybrids) } \\
\hline TENS-CO & $0.46 \pm 0.05$ & $2.04 \pm 0.11$ & $1.85 \pm 0.01$ \\
\hline Standard SDS (modified from Tai and Tanksley [20]) & $0.10 \pm 0.01$ & $1.61 \pm 0.07$ & $1.96 \pm 0.02$ \\
\hline \multicolumn{4}{|l|}{ Cereal } \\
\hline \multicolumn{4}{|l|}{ Rice (Oryza sativa L. sp. japonica) } \\
\hline TENS-CO & $0.35 \pm 0.05$ & $2.18 \pm 0.07$ & $1.93 \pm 0.01$ \\
\hline MO BIO PowerPlant Pro Kit & $0.10 \pm 0.01$ & $2.02 \pm 0.05$ & $1.84 \pm 0.01$ \\
\hline \multicolumn{4}{|l|}{ Citrus } \\
\hline \multicolumn{4}{|l|}{ Sweet orange (Citrus sinensis L. cv. Hamlin) } \\
\hline TENS-CO & $0.64 \pm 0.08$ & $2.08 \pm 0.04$ & $2.00 \pm 0.01$ \\
\hline Standard CTAB (modified from Chee et al. [43]) & $0.12 \pm 0.01$ & $2.32 \pm 0.09$ & $1.92 \pm 0.02$ \\
\hline \multicolumn{4}{|l|}{ Vegetables } \\
\hline \multicolumn{4}{|l|}{ Potato (Solanum tuberosum L. cv. Atlantic) } \\
\hline TENS-CO & $0.50 \pm 0.04$ & $2.23 \pm 0.006$ & $1.91 \pm 0.04$ \\
\hline MO BIO PowerPlant Pro Kit & $0.05 \pm 0.004$ & $2.41 \pm 0.05$ & $1.94 \pm 0.03$ \\
\hline Synergy Plant DNA Kit & $0.20 \pm 0.01$ & $2.18 \pm 0.05$ & $1.93 \pm 0.02$ \\
\hline \multicolumn{4}{|l|}{ Tomato (Solanum lycopersicum L. cv. Lance) } \\
\hline TENS-CO & $0.66 \pm 0.06$ & $2.10 \pm 0.05$ & $1.93 \pm 0.01$ \\
\hline MO BIO PowerPlant Pro Kit & $0.05 \pm 0.004$ & $1.87 \pm 0.08$ & $1.80 \pm 0.01$ \\
\hline Synergy Plant DNA Kit & $0.11 \pm 0.01$ & $1.93 \pm 0.03$ & $1.81 \pm 0.01$ \\
\hline
\end{tabular}

CTAB cetyltrimethylammonium bromide and SDS sodium dodecyl sulfate

potato plants than in non-infected ones, respectively (Fig. $4 \mathrm{a}$ and $\mathrm{b}$ ). The detection of different levels of Lso in all tested samples indicates that the TENS-CO DNA is of high quality to generate reproducible detection of microbial pathogens in host tissue.

\section{DNA isolated with the TENS-CO method is successfully used for marker-assisted selection}

Crop cultivar development can be accelerated by the utilization of molecular tools that can reduce the time and cost of screening plants with desired traits. Marker-assisted selection has been successfully used in the selection of several specific genes/alleles for crop improvement to trace favorable alleles, pyramid desired genes into one genetic background, eliminate unwanted traits by breaking undesirable linkage, and increase the frequency of desired alleles in early segregating populations [56].
A major disease affecting tomato production worldwide, especially in tropical and subtropical areas is TYLCV, vectored by whiteflies (Bemisia tabaci). Once tomato plants are infected, leaves curl upward and show strong crumpling, interveinal, and marginal yellowing, negatively impacting yield. Several major resistance genes for TYLCV have been identified, including the Ty3 gene from tomato wild-relative S. chilense [57]; however, this gene needs to be introgressed and stacked into locally adapted cultivars to ensure long-lasting disease resistance. Since marker-assisted selection requires genotyping large segregating populations, nucleic acid isolation methods that are simple, rapid and efficient will be useful. In order to test the TENS-CO method for markerassisted breeding purposes, tomato plants from $\mathrm{F}_{2}$ segregating populations carrying the $T y-3$ resistance gene were evaluated for the presence or absence of the linked codominant SCAR marker P6-25. PCR amplification using 


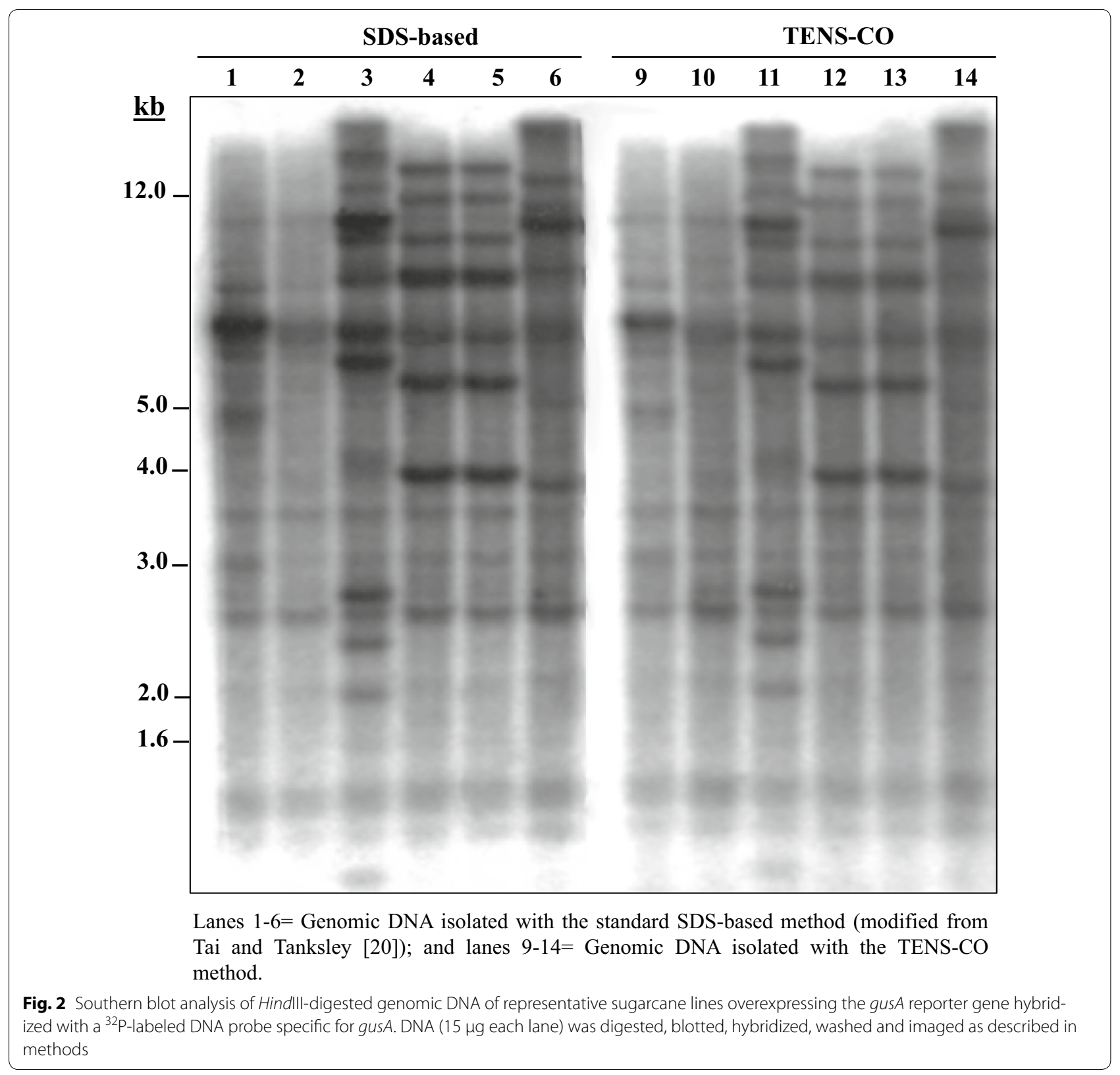

DNA extracted with the TENS-CO method resulted in distinct P6-25 polymorphic amplicons linked to the $T y$ 3 resistance gene (Fig. 5a). The amplicons obtained with DNA from the TENS-CO method were of the same size but of a higher intensity than those generated with DNA from the standard CTAB method (Fig. 5a, b). The 450base pair (bp) and 650-bp fragments are linked to $T y-3$ resistance locus introgressed from S. chilense accessions LA2779 (Ty-3) and LA1932 (Ty-3a), respectively; while the 320-bp fragment corresponded to the sequence of 


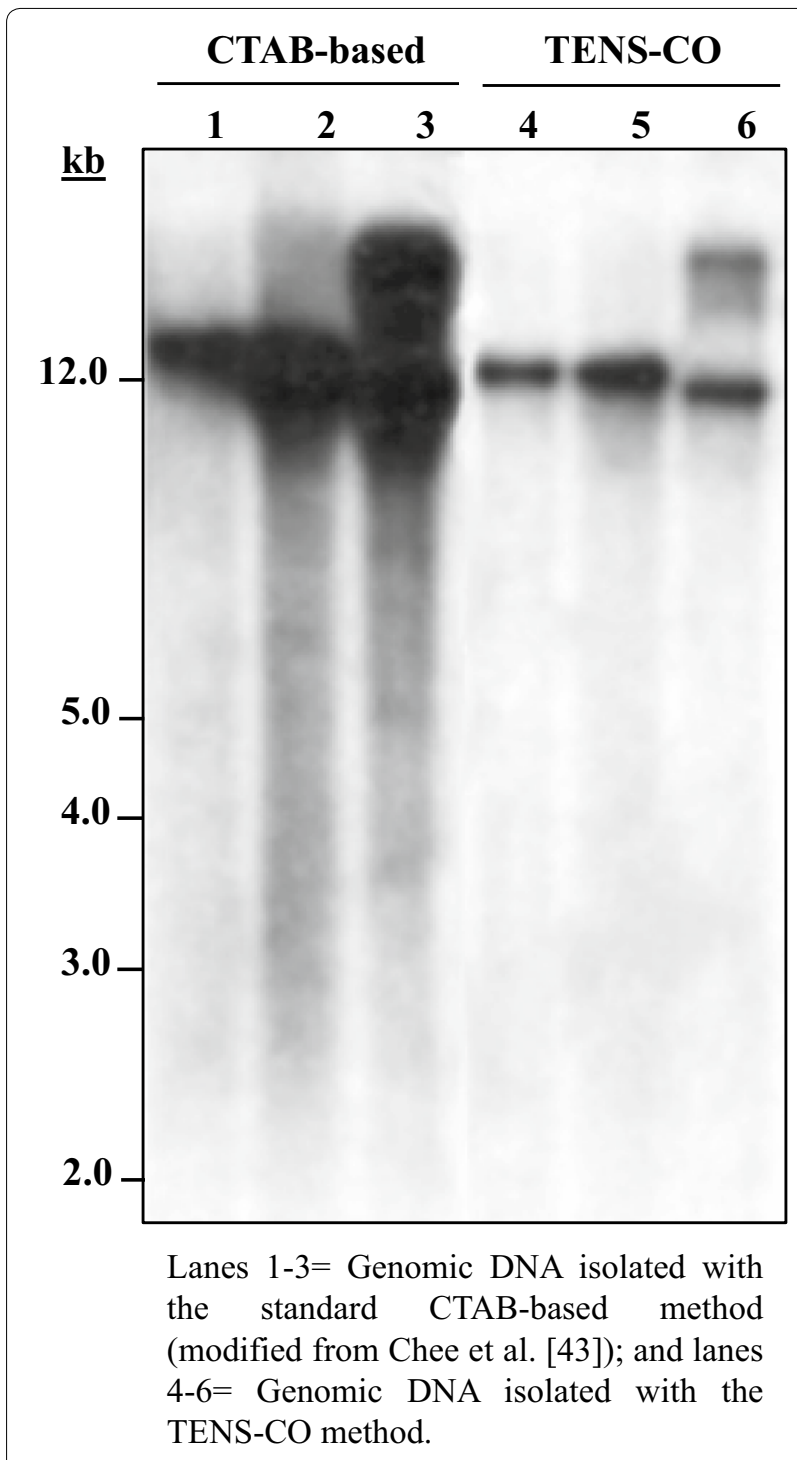

Fig. 3 Southern blot analysis of Sacl-digested genomic DNA of representative citrus (sweet orange) lines overexpressing the gus $A$ reporter gene hybridized with a ${ }^{32} \mathrm{P}$-labeled DNA probe specific for gusA. DNA (15 $\mu \mathrm{g}$ each lane) was digested, blotted, hybridized, washed and imaged as described in methods

the cultivated susceptible S. lycopersicum (ty-3) [57]. By this procedure, resistant homozygous and heterozygous plants can be distinguished from susceptible homozygous plants prior to field evaluation. DNA extraction with the TENS-CO method is cost effective, time saving, and amenable for semi-automated genotyping to screen

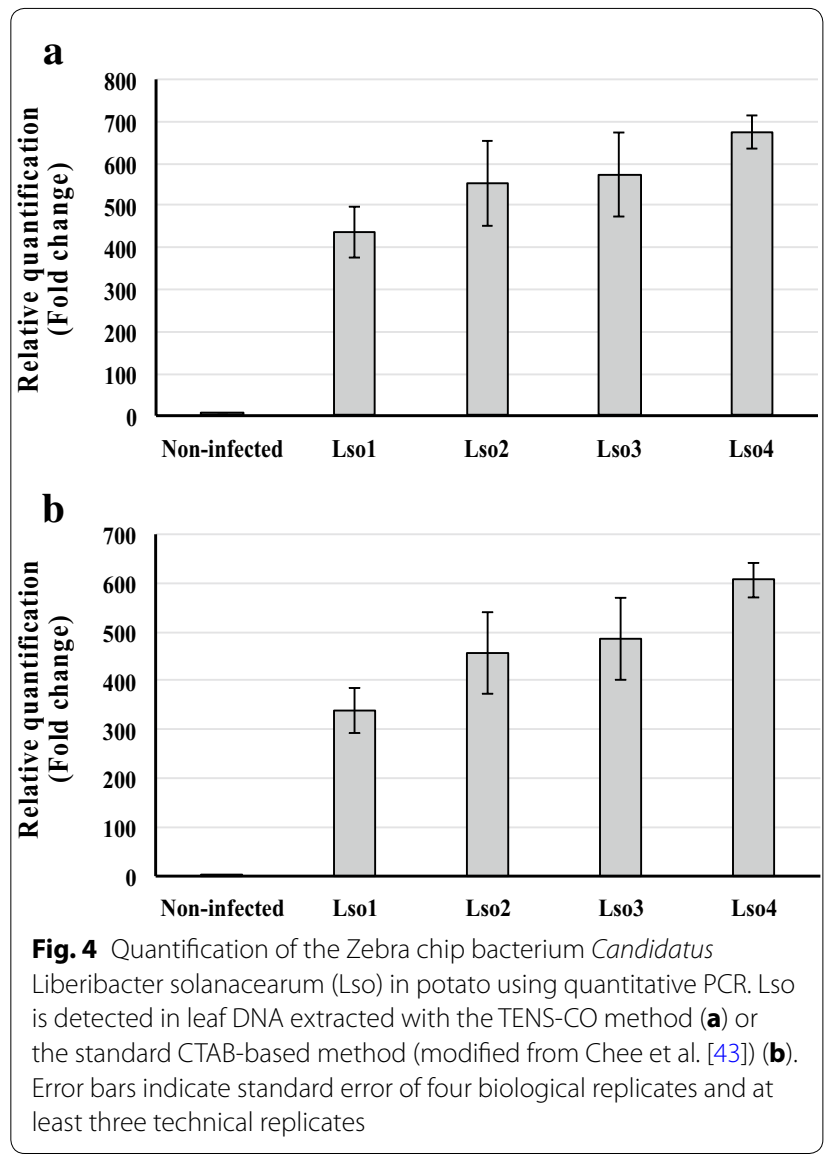

large populations using conventional molecular laboratory equipment as part of a marker-assisted selection program.

\section{Conclusions}

Genomic DNA isolation procedures have improved drastically over the past decade and are a powerful tool in molecular genetic and genomic research. To facilitate molecular genetic studies in major agronomic crops, we have developed a simple, rapid, reproducible and scalable protocol enabling efficient and robust isolation of highquality and -quantity DNA from sugarcane, rice, citrus, potato, and tomato, thereby reducing significantly the time and resources used for DNA isolation. Compared to other protocols, the TENS-CO method is a simplified method consisting of one extraction step, using SDS and chloroform with 2-mercaptoethanol as an antioxidant, and one step of precipitation (sodium acetate/ethanol). We have demonstrated that the method accelerates 


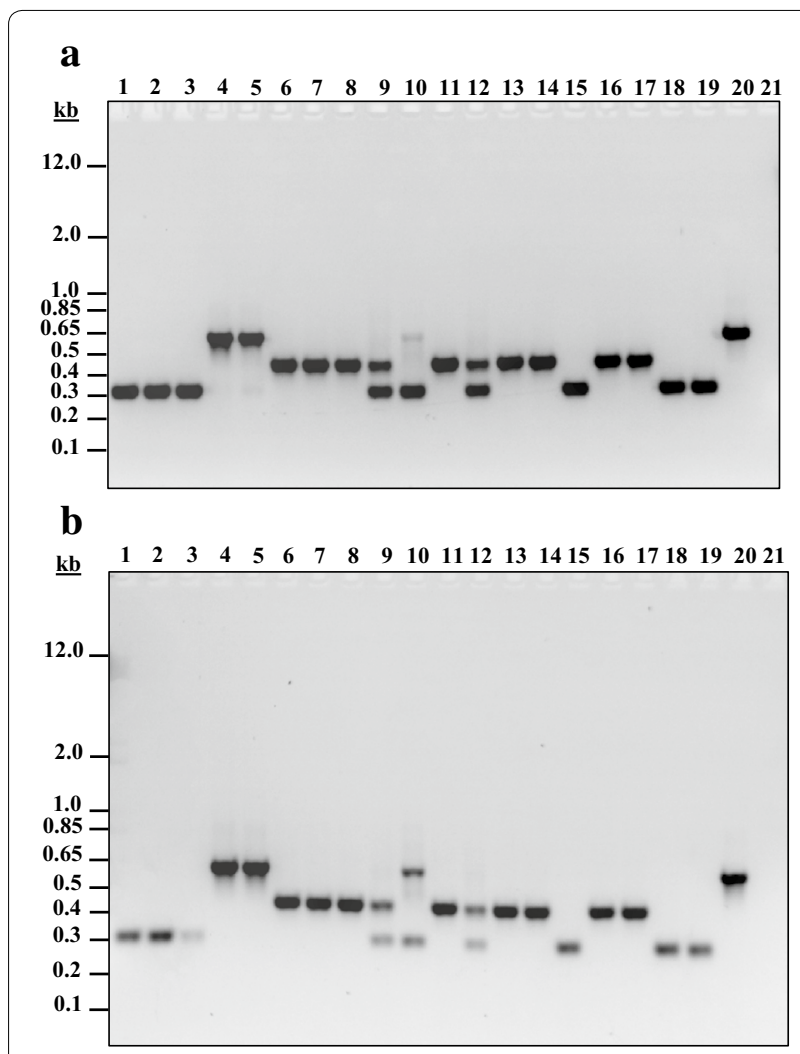

Lanes $1-3=t y-3 / t y-3 ;$ lanes $4-5=T y-3 a / T y-3 a$; lanes $6-8=T y$ $3 / T y-3$; lane $9=T y-3 / t y-3$; lane $10=T y-3 a / t y-3$; lane $11=T y-$ 3/Ty-3; lane $12=T y-3 / t y-3$; lanes $13-14=T y-3 / T y-3$; lane $15=$ ty-3/ty-3; lanes $16-17=T y-3 / T y-3$; lanes $18-19=t y-3 / t y-3$; lane $20=T y-3 a / T y-3 a$; and lane $21=$ No template control.

Fig. 5 Marker-assisted selection using the co-dominant SCAR marker P6-25 linked to Ty3 resistance gene in tomato [57]. PCR amplicons from DNA extracted with the TENS-CO method (a) or the standard CTAB-based method (modified from Chee et al. [43]) (b); were separated by electrophoresis on a 1.5\% (w/v) agarose gel

\section{Authors' contributions}

KTC, MBD, CSP, CAA and SRP conceived and designed the experiments. KTC, CSP, SRP, NRR, MBD and DVC performed the experiments. KTC, MBD, SRP, CSP, CAA and DVC analyzed the data. MBD, KTC, CSP, CAA, SRP, TEM and KKM contributed to manuscript preparation. All authors read and approved the final manuscript.

\section{Author details}

${ }^{1}$ Texas A\&M AgriLife Research and Extension Center, 2415 East US Highway 83, Weslaco, TX 78596, USA. ${ }^{2}$ Department of Horticultural Sciences, Texas A\&M University, 2133 TAMU, College Station, TX 77843, USA. ${ }^{3}$ Department of Plant Pathology and Microbiology, Texas A\&M University, 2132 TAMU, College Station, TX 77843, USA. ${ }^{4}$ Present Address: Department of Plant Pathology and Microbiology, Texas A\&M University, 2132 TAMU, College Station, TX 77843, USA. ${ }^{5}$ Present Address: FuturaGene Ltd, Av. Dr. José Lembo, \#1010 Bairro, Jardim Bela Vista, Itapetininga, São Paulo, Brazil.

\section{Acknowledgements}

The authors wish to thank Joe Molina and Denise Rossi (Texas A\&M AgriLife Research) for excellent technical support.

\section{Competing interests}

The authors declare that they have no competing interests.

\section{Availability of data and materials}

All data generated or analyzed during this study are included in this manuscript and its supplementary information file (Additional file 1: Table S1).

\section{Ethics and consent}

Not applicable.

\section{Funding}

This study was funded by Southern Gardens Citrus (Clewiston, Florida) to T.E.M., Texas A\&M Agrilife Research Bioenergy/Bioproducts Grant to K.K.M., and Texas A\&M AgriLife Research Grant FY16 124185-96180 to C.A.A.

All experiments have been conducted following the guidelines of Texas A\&M University Institutional Biosafety Committee.

\section{Publisher's Note}

Springer Nature remains neutral with regard to jurisdictional claims in published maps and institutional affiliations.

Received: 12 July 2017 Accepted: 20 November 2017 Published online: 02 December 2017

screening of large amounts of plant tissues from species that are rich in polysaccharides and secondary metabolites for Southern blot analysis, marker-assisted selection and quantitative PCR applications.

\section{Additional file}

Additional file 1: Table S1. Comparison of the TENS-CO method with other DNA isolation procedures used for plant species with high level of secondary metabolites.

\section{Abbreviations}

BAR: bialaphos resistance; $C_{T}$ : threshold cycle; CTAB: cetyltrimethylammonium bromide; EDTA: ethylenediamine-tetraacetic acid; GUS: $\beta$-glucuronidase; KOAC: potassium acetate; Lso: Candidatus Liberibacter solanacearum; $\mathrm{NaCl}$ : sodium chloride; PVP: polyvinylpyrrolidone; qPCR: quantitative polymerase chain reaction; RPL2: tomato ribosomal protein L2; SCAR: sequence characterized amplified regions; SHDIR16: Saccharum spp. hybrids dirigent16; SDS: sodium dodecyl sulfate; TYLCV: tomato yellow leaf curl virus; Ubi1: maize ubiquitin 1.

\section{References}

1. Japelaghi RH, Haddad R, Garoosi G-A. Rapid and efficient isolation of high quality nucleic acids from plant tissues rich in polyphenols and polysaccharides. Mol Biotechnol. 2011;49:129-37.

2. Khanuja SPS, Shasany AK, Darokar MP, Kumar S. Rapid isolation of DNA from dry and fresh samples of plants producing large amounts of secondary metabolites and essential oils. Plant Mol Biol Rep. 1999;17:74.

3. Lade BD, Patil AS, Paikrao HM. Efficient genomic DNA extraction protocol from medicinal rich Passiflora foetida containing high level of polysaccharide and polyphenol. SpringerPlus. 2014;3:457.

4. Peterson DG, Boehm KS, Stack SM. Isolation of milligram quantities of nuclear DNA from tomato (Lycopersicon esculentum), a plant containing high levels of polyphenolic compounds. Plant Mol Biol Rep. 1997;15:148-53.

5. Porebski S, Bailey LG, Baum BR. Modification of a CTAB DNA extraction protocol for plants containing high polysaccharide and polyphenol components. Plant Mol Biol Rep. 1997;15:8-15.

6. Chaves MM, Maroco JP, Pereira JS. Understanding plant responses to drought-from genes to the whole plant. Funct Plant Biol. 2003;30:239-64.

7. Winkel-Shirley B. Molecular genetics and control of anthocyanin expression. Adv Bot Res. 2002;37:75-94. 
8. Chen Y-N, Wei W-H, Ren X-P, Zhao X-Y, Zhou X-J, Huang L, Tang X-C, Jiang $\mathrm{H}-\mathrm{F}$. Construction of a high-quality genomic BAC library for Chinese peanut cultivar Zhonghua 8 with high oil content. Bot Stud. 2014;55:8.

9. Collard BCY, Mackill DJ. Marker-assisted selection: an approach for precision plant breeding in the twenty-first century. Philos Trans R Soc Lond B Biol Sci. 2008;363:557-72.

10. Li Q-B, Cai Q, Guy CL. A DNA extraction method for RAPD analysis from plants rich in soluble polysaccharides. Plant Mol Biol Rep. 1994;12:215-20.

11. Padmalatha K, Prasad MNV. Optimization of DNA isolation and PCR protocol for RAPD analysis of selected medicinal and aromatic plants of conservation concern from Peninsular India. Afr J Biotechnol. 2006;5:230-4.

12. Bekesiova I, Nap J-P, Mlynarova L. Isolation of high quality DNA and RNA from leaves of the carnivorous plant Drosera rotundifolia. Plant Mol Biol Rep. 1999;17:269-77.

13. Doyle JJ, Doyle JL. A rapid DNA isolation procedure for small quantities of fresh leaf tissue. Phytochem Bull. 1987;19:11-5.

14. Murray MG, Thompson WF. Rapid isolation of high molecular weight plant DNA. Nucleic Acids Res. 1980;8:4321-6.

15. Manubens A, Lobos S, Jadue Y, Toro M, Messina R, Lladser M, Seelenfreund D. DNA isolation and AFLP fingerprinting of nectarine and peach varieties (Prunus persica). Plant Mol Biol Rep. 1999;17:255-67.

16. Wagner DB, Furnier GR, Saghai-Maroof MA, Williams SM, Dancik BP, Allard RW. Chloroplast DNA polymorphisms in lodgepole and jack pines and their hybrids. Proc Natl Acad Sci USA. 1987;84:2097-100.

17. Aljanabi SM, Martinez I. Universal and rapid salt-extraction of high quality genomic DNA for PCR-based techniques. Nucleic Acids Res. 1997;25:4692-3.

18. Dellaporta SL, Wood J, Hicks JB. A plant DNA minipreparation: version II. Plant Mol Biol Rep. 1983;1:19-21.

19. Ferrari CDS, Valente LL, Brod FCA, Tagliari C, Sant'Anna ES, Arisi ACM. Evaluation of polymerase chain reaction and DNA isolation protocols for detection of genetically modified soybean. Int J Food Sci Technol. 2007:42:1249-55.

20. Tai TH, Tanksley SD. A rapid and inexpensive method for isolation of total DNA from dehydrated plant tissue. Plant Mol Biol Rep. 1990;8:297-303.

21. Lin J-J, Kuo J. A new reagent for simple isolation of plant genomic DNA. Focus. 1998;20:46-8.

22. Ouenzar B, Hartmann C, Rode A, Benslimane A. Date palm DNA minipreparation without liquid nitrogen. Plant Mol Biol Rep. 1998;16:263-9.

23. Drábková L, Kirschner JAN, Vlĉek C. Comparison of seven DNA extraction and amplification protocols in historical herbarium specimens of Juncaceae. Plant Mol Biol Rep. 2002;20:161-75.

24. Scaldaferri MM, Freitas JS, Santos ESL, Vieira JGP, Gonçalves ZS, CerqueiraSilva CBM. Comparison of protocols for genomic DNA extraction from 'velame pimenta'(Croton linearifolius), a native species to the Caatinga, Brazil. Afr J Biotechnol. 2013;12:4761-6.

25. Barnwell P, Blanchard AN, Smirnoff N, Weir AF. Isolation of DNA from the highly mucilagenous succulent plant shape Sedum telephium. Plant Mol Biol Rep. 1998;16:133-8.

26. De La Cruz M, Ramirez F, Hernandez H. DNA isolation and amplification from cacti. Plant Mol Biol Rep. 1997;15:319-25.

27. Devey ME, Bell JC, Smith DN, Neale DB, Moran GF. A genetic linkage map for Pinus radiata based on RFLP, RAPD, and microsatellite markers. Theor Appl Genet. 1996;92:673-9.

28. Kim CS, Lee CH, Shin JS, Chung YS, Hyung NI. A simple and rapid method for isolation of high quality genomic DNA from fruit trees and conifers using PVP. Nucleic Acids Res. 1997:25:1085-6.

29. Lodhi MA, Ye G-N, Weeden NF, Reisch BI. A simple and efficient method for DNA extraction from grapevine cultivars and Vitis species. Plant Mol Biol Rep. 1994;12:6-13.

30. Stewart CN Jr, Via LE. A rapid CTAB DNA isolation technique useful for RAPD fingerprinting and other PCR applications. Biotechniques. 1993; 14:748-50

31. Tel-Zur N, Abbo S, Myslabodski D, Mizrahi Y. Modified CTAB procedure for DNA isolation from epiphytic cacti of the genera Hylocereus and Selenicereus (Cactaceae). Plant Mol Biol Rep. 1999;17:249-54.

32. Tibbits JFG, McManus LJ, Spokevicius AV, Bossinger G. A rapid method for tissue collection and high-throughput isolation of genomic DNA from mature trees. Plant Plant Mol Biol Rep. 2006;24:81-91.
33. Ivanova NV, Fazekas AJ, Hebert PDN. Semi-automated, membrane-based protocol for DNA isolation from plants. Plant Mol Biol Rep. 2008;26:186.

34. Csaikl UM, Bastian H, Brettschneider R, Gauch S, Meir A, Schauerte M, Scholz F, Sperisen C, Vornam B, Ziegenhagen B. Comparative analysis of different DNA extraction protocols: a fast, universal maxi-preparation of high quality plant DNA for genetic evaluation and phylogenetic studies. Plant Mol Biol Rep. 1998;16:69-86.

35. Yang ZN, Ingelbrecht IL, Louzada E, Skaria M, Mirkov TE. Agrobacteriummediated transformation of the commercially important grapefruit cultivar Rio Red (Citrus paradisi Macf.). Plant Cell Rep. 2000;19:1203-11.

36. Hood EE, Gelvin SB, Melchers LS, Hoekema A. New Agrobacterium helper plasmids for gene transfer to plants. Transgenic Res. 1993;2:208-18.

37. Damaj MB, Kumpatla SP, Emani C, Beremand PD, Reddy AS, Rathore KS, Buenrostro-Nava MT, Curtis IS, Thomas TL, Mirkov TE. Sugarcane DIRIGENT and O-methyltransferase promoters confer stem-regulated gene expression in diverse monocots. Planta. 2010;231:1439-58.

38. Aldemita RR, Hodges TK. Agrobacterium tumefaciens-mediated transformation of japonica and indica rice varieties. Planta. 1996;199:612-7.

39. Christensen AH, Quail PH. Ubiquitin promoter-based vectors for highlevel expression of selectable and/or screenable marker genes in monocotyledonous plants. Transgenic Res. 1996;5:213-8.

40. Gao S-J, Damaj MB, Park J-W, Beyene G, Buenrostro-Nava MT, Molina J, Wang X, Ciomperlik JJ, Manabayeva SA, Alvarado VY. Enhanced transgene expression in sugarcane by co-expression of virus-encoded RNA silencing suppressors. PLoS ONE. 2013;8:e66046. https://doi.org/10.1371/journal.pone.0066046.

41. Chee PP, Drong RF, Slightom JL. Using polymerase chain reaction to identify transgenic plants. In: Gelvin SB, Schilperoort RA, Verma DPS, editors. Plant molecular biology manual. Dordrecht: Springer; 1991. p. 1-28.

42. Koetsier PA, Schorr J, Doerfler W. A rapid optimized protocol for downward alkaline Southern blotting of DNA. Biotechniques. 1993;15:260-2.

43. Mangwende T, Wang M-L, Borth W, Hu J, Moore PH, Mirkov TE, Albert HH. The PO gene of Sugarcane yellow leaf virus encodes an RNA silencing suppressor with unique activities. Virology. 2009;384:38-50.

44. Crosslin JM, Lin H, Munyaneza JE. Detection of 'Candidatus Liberibacter Solanacearum'in the potato psyllid, Bactericera cockerelli (Sulc) 1, by conventional and real-time PCR. Southwest Entomol. 2011;36:125-35.

45. Avila CA, Arévalo-Soliz LM, Jia L, Navarre DA, Chen Z, Howe GA, Meng Q-W, Smith JE, Goggin FL. Loss of function of FATTY ACID DESATURASE7 in tomato enhances basal aphid resistance in a salicylate-dependent manner. Plant Physiol. 2012;158:2028-41.

46. Livak KJ, Schmittgen TD. Analysis of relative gene expression data using real-time quantitative PCR and the $2^{-\Delta \Delta \mathrm{Ct}}$ method. Methods. 2001;25:402-8.

47. JiY, Salus MS, van Betteray B, Smeets J, Jensen KS, Martin CT, Mejia L, Scott JW, Havey MJ, Maxwell DP. Co-dominant SCAR markers for detection of the Ty-3 and Ty-3a loci from Solanum chilense at $25 \mathrm{cM}$ of chromosome 6 of tomato. Tomato Genet Coop Rep. 2007;57:25-8.

48. Fang G, Hammar S, Grumet R. A quick and inexpensive method for removing polysaccharides from plant genomic DNA. Biotechniques. 1992:13(52-4):56.

49. Vaze A, Nerkar G, Pagariya M, Devarumath RM, Prasad DT. Isolation and PCR amplification of genomic DNA from dry leaf samples of sugarcane. Int J Pharma Bio Sci. 2010;1:1-6.

50. Honeycutt RJ, Sobral BWS, Keim P, Irvine JE. A rapid DNA extraction method for sugarcane and its relatives. Plant Mol Biol Rep. 1992;10:66-72.

51. Peterson DG, Schulze SR, Sciara EB, Lee SA, Bowers JE, Nagel A, Jiang N, Tibbitts DC, Wessler SR, Paterson AH. Integration of Cot analysis, DNA cloning, and high-throughput sequencing facilitates genome characterization and gene discovery. Genome Res. 2002;12:795-807.

52. Hansen AK, Trumble JT, Stouthamer R, Paine TD. A new huanglongbing species, "Candidatus Liberibacter psyllaurous", found to infect tomato and potato, is vectored by the psyllid Bactericera cockerelli (Sulc). Appl Environ Microbiol. 2008;74:5862-5.

53. Wen A, Mallik I, Alvarado VY, Pasche JS, Wang X, Li W, Levy L, Lin H, Scholthof HB, Mirkov TE. Detection, distribution, and genetic variability of 'Candidatus Liberibacter'species associated with Zebra complex disease of potato in North America. Plant Dis. 2009;93:1102-15. 
54. Munyaneza JE, Crosslin JM, Upton JE. Association of Bactericera cockerelli (Homoptera: Psyllidae) with "zebra chip", a new potato disease in southwestern United States and Mexico. J Econ Entomol. 2007;100:656-63.

55. Beard SS, Pitman AR, Kraberger S, Scott IAW. SYBR Green real-time quantitative PCR for the specific detection and quantification of 'Candidatus Liberibacter solanacearum' in field samples from New Zealand. Eur J Plant Pathol. 2013;136:203-15.
56. Foolad MR, Panthee DR. Marker-assisted selection in tomato breeding. Crit Rev Plant Sci. 2012;31:93-123.

57. Ji Y, Schuster DJ, Scott JW. Ty-3, a begomovirus resistance locus near the Tomato yellow leaf curl virus resistance locus Ty-1 on chromosome 6 of tomato. Mol Breed. 2007;20:271-84.

\section{Submit your next manuscript to BioMed Central and we will help you at every step:}

- We accept pre-submission inquiries

- Our selector tool helps you to find the most relevant journal

- We provide round the clock customer support

- Convenient online submission

- Thorough peer review

- Inclusion in PubMed and all major indexing services

- Maximum visibility for your research

Submit your manuscript at

www.biomedcentral.com/submit 